\title{
Subsidence at the "Trébol” of Quito, Ecuador: an indicator for future disasters?
}

\author{
T. Toulkeridis ${ }^{1}$, D. Simón Baile ${ }^{1}$, F. Rodríguez ${ }^{1}$, R. Salazar Martínez ${ }^{1}$, N. Arias Jiménez ${ }^{2}$, and \\ D. Carreon Freyre ${ }^{3}$ \\ ${ }^{1}$ Universidad de las Fuerzas Armadas ESPE, Sangolquí, Ecuador \\ ${ }^{2}$ Empresa Metropolitana de Alcantarrillado y Agua Potable de Quito, Quito, Ecuador \\ ${ }^{3}$ Universidad Nacional Autónoma de México, Queretaro, Mexico \\ Correspondence to: T. Toulkeridis (ttoulkeridis@espe.edu.ec)
}

Published: 12 November 2015

\begin{abstract}
A sinkhole of great proportions was produced in one of the most trafficked zones of Quito. Constructed in the late sixties, this area is of high importance in solving the traffic jams of the capital city. The sinkhole called "El Trebol" started to be generated in the form of a crater, reached finally dimensions of approximately $120 \mathrm{~m}$ in diameter and some $40 \mathrm{~m}$ of depth, where at its base the river Machangara appeared. The generation of this sinkhole paralyzed the traffic of the south-central part of the city for the following weeks and therefore the state of emergency was declared. Soon the cause of the sinkhole was encountered being the result of the lack of monitoring of the older subterranean sewer system where for a length of some $20 \mathrm{~m}$ the concrete tunnel that canalized the flow of the river collapsed generating the disaster. The collapse of this tunnel resulted from the presence of a high amount of trash floating through the tunnel and scratching its top part until the concrete was worn away leaving behind the sinkhole and the fear of recurrence in populated areas. The financial aspects of direct and indirect damage are emphasized.
\end{abstract}

\section{Introduction to the event and its causes}

On Monday, 31 March 2008, around 14:00 LT, a giant subsidence in form of a sinkhole has been generated in a site called "El Trebol", where $25000 \mathrm{~m}^{3}$ of earthy material disappeared. This area is the most important southern inter-connector of the city to the Valley "De los Chillos" in the eastern end of Quito, but serves as well to connect the southern to the northern side of the city, where an extremely high amount of vehicles transit daily. This site was constructed four decades before its collapse. The sinkhole started in form of a crater with a diameter of approximately $30 \mathrm{~m}$, amplifying its size constantly due to the instability of the slopes, which being wet and saturated with water of the high precipitations in that area of those days prior to the event. Further presence of more subterranean water has been noticed in the southern slope of the sinkhole, when the diameter reached some $120 \mathrm{~m}$ in diameter and a depth of $40 \mathrm{~m}$, determined from the top part down to the previously covered river. That river was detected after the visible collapse of the concrete channel- ing which leads the river Machangara for a distance of some $20 \mathrm{~m}$. Fortunately, no victims where reported. The result of this subsidence has been a traffic collapse and the declaration of the state of emergency of the Municipality of Quito. This event forced the authorities of Quito first to find out the causes of this subsidence and afterwards to search for further areas with similar problems and vulnerabilities in order to avoid future disasters where potentially people could be involved.

Three hypothesis were taken into consideration as the most potential cause for this disaster: (a) extreme discharge, (b) erosional process and chemical activity through time and finally (c) activity o subterranean waters, of which it resulted to be a combination of all three causes in different proportions. 
Table 1. INAMHI's Meteorological Automatic Stations closest to El Trébol area.

\begin{tabular}{llrrr}
\hline Code & $\begin{array}{l}\text { Station } \\
\text { name }\end{array}$ & Latitude & Longitude & $\begin{array}{r}\text { Altitude } \\
(\mathrm{m})\end{array}$ \\
\hline M003 & Izobamba & -0.366089 & -78.555061 & 3085.00 \\
M024 & Iñaquito & -0.175000 & -78.485278 & 2789.12 \\
M002 & La Tola & -0.231667 & -78.370333 & 2503.00 \\
\hline
\end{tabular}

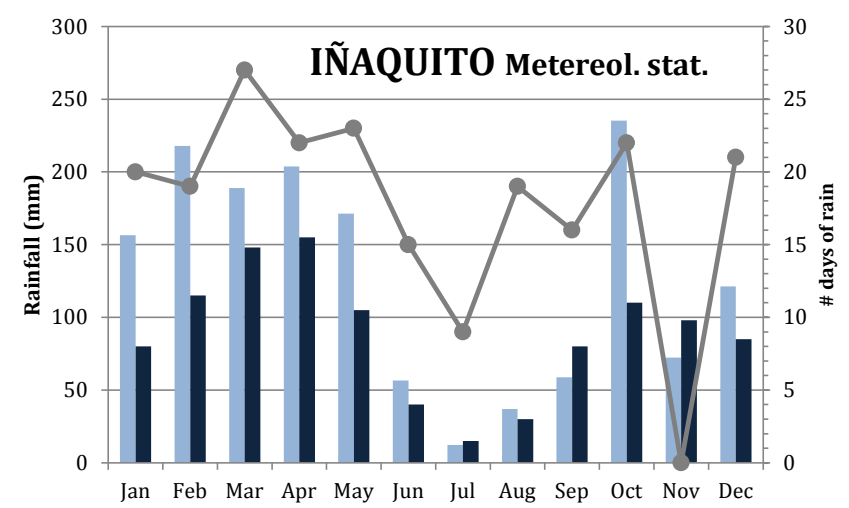

Figure 1. Total monthly rainfall, average multiannual rainfall (of the available data) number of days with rain per month (higher than $0.1 \mathrm{~mm}$ ) of the closest meteorological station to El Trebol being Iñaquito. From National Institute of Meteorology and Hydrology (2010).

\section{Hydrological characteristics}

The hydrographic network of the South Valley of Quito is classified as dendritic, having the Machángara as its main river course. The Machángara rises in the steep foothills of volcano Atacazo and crosses the valley from south-west to north-east running parallel to the basin until it reaches the Trébol area (Panecillo) where it takes a turn to the East, gets deeper and flows to the valleys of Cumbayá and Tumbaco. Another important drainage is the so-called "Quebrada Grande" that has its source in the northwest foothills of volcano Atacazo and for a strecht it runs parallel to the Machángara river until it becomes its tributary. When it exits to the valley, the same river caudal varies between $3 \mathrm{~m}^{3} \mathrm{~s}^{-1}$ during dry season and $170 \mathrm{~m}^{3} \mathrm{~s}^{-1}$ during the wet season. Furthermore, the Machángara river is the main sewage receiver of Quito.

Regarding rainfall, the distribution along the year shows the prevalence of two periods with abundant rainfall being these, February-May and October-November respectively, (EMAAP-Q, 2006; Table 1, Fig. 1). On the other hand, as for the multiannual distribution of rainfall it is important to highlight that the wet season between January and March 2008 was considered the strongest of the last 20 years with accumulated rainfall during the first 3 months of 2008 being much higher that the recorded during any other heavy rainy seasons of 1989, 1993 and 2000 (Salazar et al., 2009). In particular, a peak of $21.2 \mathrm{~L} \mathrm{~m}^{-2}$ was registered on 31 March 2008 during a heavy rainfall that lasted $4 \mathrm{~h}$ from 1 to 5 p.m. (INAMHI, 2008; El Comercio, 2008; Salazar et al., 2009). Furthermore, within the whole year 2008 and coinciding in the three meteorological stations closest to "El Trébol", March recorded continuous raining since it was the month with the highest number of days of rain, with 27 and 29 out of 31 days in Iñaquito and Izobamba respectively (Fig. 1.)

\section{Historical background of the area}

The site where El Trébol was constructed is about 300$600 \mathrm{~m}$. downstream of the confluence of Jerusalem and El Tejar streams, with Machángara River. Today, the channeled stream of Jerusalem is the Boulevard 24 de Mayo Avenue and its extension to the old bus station, current Qumandá Park. The channeled stream of El Tejar, after passing below the historic center, merges and flows with the stream of Manosalvas down in the low neighborhood of San Juan, in the area that is the center of mass transit transfer, now known as La Marin, before reaching Machángara River.

As a result of uncontrolled growth of the city, this natural drainage system was conducted on sewer channels below the construction of roads for vehicular traffic, and historically have been recorded 12 sinkholes (Fig. 2a) of different magnitudes, defined as "declines or collapses of roadway in the filler material streams, caused by faulty sewers". The responsibility gets under the fill type initially performed with debris and garbage, as well as the age, type of construction and degree of deterioration of the physical work of the channels, sewers and collectors (Pewter, 1986; Fig. 2b). The location of these sinkholes is defined about the old bed of the streams filled so we can assume that on its way continue to occur, especially in periods of daily rainfall above the historical average. In the area of EL Trébol, the first serious collapse was registered on 31 March 2008 and took ten years after the river and fill channels were made for the construction of the infrastructure to solve the problems of the traffic jams. There was a second sink lower rates on 10 January 2014 (Fig. 2c).

\section{Direct and indirect financial damage}

The day after sinkhole, the Ecuadorean Government created a line of credit of USD 60 million to help the city and start the reconstruction (La Hora, 2008). At the same day, the Quito's Major and the City's Council created an emergency fund of USD 200000 . This emergency fund was increased to about USD 1 million.

The day after drainage vault collapsed, rebuilding process started with a team of 5 hydraulic excavators, 5 power shovels, 10 roll-off trucks, 4 system equipment of mobile industrial lighting. In the rebuilding process 210 workers teams were at the site 24/7 (Explored, 2009). The reconstruction of 
a)

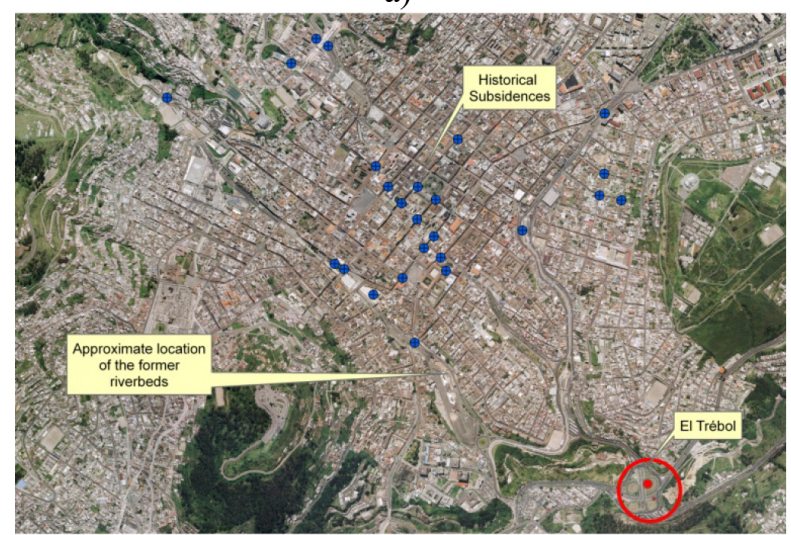

b)

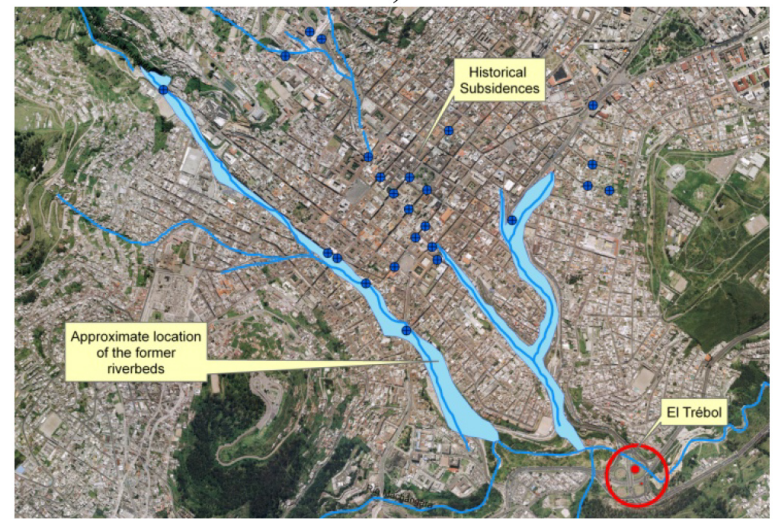

c)

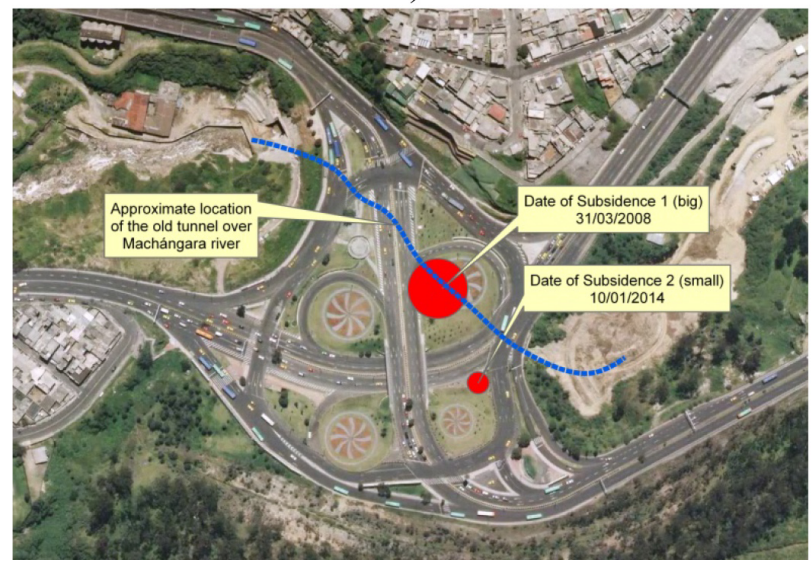

Figure 2. (a-c) Historical subsidences at Machángara river, El Trébol sector.

the cloverleaf interchange took 8 months to full traffic recovery, yet the entire reconstruction of the site took 22 months (Explored, 2010). El Trebol total reconstruction cost reached over USD 13 million, yet it did not required to use the full line of credit; details of expenditures are presented in Table 2.

However, this cost did not reflect the real cost because it does not take in account the externalities implicit with the sinkhole. Externalities associated to how users were affected by the sinkhole and cloverleaf interchange reconstruction. For instance, local authorities closed schools during the first week after the event, cost of students losing classes are not included neither teachers income lost, who were in per hour contracts.

We analyzed those costs of users who were affected by and were not compensated for. Because of lack of official information, we concentrated our efforts to estimate the cost of losing time during the reconstruction of the cloverleaf interchange and drainage vault, as well as the additional cost in gasoline of users of this crucial cloverleaf interchange.
Table 2. List of the costs of the reconstruction in USD (Source: MDMQ, 2015).

\begin{tabular}{lr}
\hline New tunnel & 7575872.21 \\
Rental of equipment & 352622.93 \\
Land movement & 151526.15 \\
Labor & 801546.35 \\
Construction materials & 435495.03 \\
Services & 219061.16 \\
Other costs & 31236.78 \\
EMOP & 2000000.00 \\
Vida para Quito & 2000000.00 \\
\hline Total & 13567360.61 \\
\hline
\end{tabular}

In case of additional cost in gasoline, there were 80000 of vehicles circulate and use El Trebol every day, in addition of 400 inter-parish buses of public transportation (La Hora, 2008). In order to estimate the value lost by users, we concentrated in private transportation under the assumption that a car-owner who uses his car to go to his job and back home 
Table 3. Vehicle type and different gasoline prices in USD.

\begin{tabular}{lrr}
\hline \multirow{2}{*}{ Vehicle } & \multicolumn{2}{c}{ Gasoline price } \\
\cline { 2 - 3 } type & USD gallon $^{-1}$ & Total cost* \\
\hline 17456 & 2.00 & 11210941.44 \\
62544 & 1.48 & 40168258.56 \\
\hline \multicolumn{2}{c}{ Total gasoline } & 51379200.00 \\
\hline * Adding USD 0.07
\end{tabular}

Table 4. Cost category expressed in delay of 25 and $35 \mathrm{~min}$.

\begin{tabular}{lrr}
\hline Cost category & $25 \mathrm{~min}$ & $35 \mathrm{~min}$ \\
\hline CPVTOTAL & 34185200.00 & 47859280.00 \\
CPSTOTAL & 15668216.67 & 21935503.33 \\
CPAvVITOTAL & 7121916.67 & 9970683.33 \\
CPúTOTAL & 11395066,67 & 15953093.33 \\
\hline Total cost & 68370400.00 & 95718560.00 \\
\hline
\end{tabular}

fills his car gas tank once a week. This assumption seems reasonable for most of car owners. Yet, we did not include public transportation because we do not know how many times a transportation unit fills bus gas tank in a week. Based on public estimations, we used a value 0.07 additional dollar that an owner has to pay extra to fill his gas tank. It is reasonable also to assume that a car owner spends USD 20 week $^{-1}$ filling his car tank. These USD 0.07 seems a low bound, but still reasonable. Then, we multiply the value of one gallon of gasoline adding these USD 0.07 .

Based on AIHE statistics (AIHE, 2015), we know that $21 \%$ of the car owners use a "super premium" gasoline which costs USD 2.00 gallon $^{-1}$ and $78 \%$ uses "extra" gasoline with a price of USD 1.48 gallon $^{-1}$. Based on the number of vehicles which circulated at that time "El Trebol" every day, 80000 cars day $^{-1}$, we can say that approximately 17000 cars used "super premium" gasoline and over 62000 used "extra" gasoline type. We estimated that additional cost in gasoline for private car owners was USD 85 million for those 8 months of traffic problems at "El Trebol" (Table 3).

We did not include capital depreciation, even now, it is public knowledge that keep a car running while waiting depreciate its value faster than normal conditions. We did not include both public transportation and car owners who own a diesel engine car.

Concerning the cost of time lost (an opportunity cost), we estimate its value from per hour salary multiply for the additional time that users had to spend during the reconstruction process. We considered that a time between 25 up to $35 \mathrm{~min}$ is reasonable to believe users lost during their travel to workplaces or going back their homes. A user lost of USD 2.2$3.12 \mathrm{~h}^{-1}$ seems to be reasonable. This value is multiplied by the total time of site reconstruction. Since user came from
Table 5. Cost category.

\begin{tabular}{lrr}
\hline Cost category & Amount (USD) & Ratio \\
\hline Reconstruction cost & 13567360.61 & \\
Additional gasoline cost & 51379200.00 & 0.264063290 \\
Opportunity cost 25 min & 68370400.00 & 0.198439100 \\
Opportunity cost 35 min & 95718560.00 & 0.141742214 \\
\hline
\end{tabular}

different directions, we estimate the lost value separately. According to media reports, 48000 came private own vehicles from "Los Chillos" Valley (CPVTOTAL), 22000 came from southern part of Quito (CPSTOTAL), 10000 were coming toward the valley or southern part of the city (CPAvVITOTAL) and 400 units of public transportation (CPúTOTAL). Regarding public transportation, we assume that each unit was carrying 40 passengers each trip, which it is a low bound because rush hour, these units can be a full capacity (around 72 passengers).

Finally we estimate users' opportunity cost multiplying per hour lost times the time of "El Trebol" reconstruction, which was total of 8 months. The users' opportunity cost for each category is presented in Table 4.

Users lost a considerable amount of time when reconstruction took place, adding all users (the aggregate value) it turned out that the real cost of the sinkhole increases significantly. As the table shows, under the assumption that users lost only $25 \mathrm{~min}$, the opportunity cost reaches over USD 68 million during the 8 months of reconstruction, and under the assumption that user lost up to $35 \mathrm{~min}$, the opportunity cost reaches over USD 95 million. As a result the real cost (under $25 \mathrm{~min}$ assumption) reached more than USD 133 million, and under 35 min assumption reached more than USD 160 million as real cost (Table 5).

\section{Conclusions and recommendations}

As result of this event, we consider as a priority to take corresponding actions to prevent future collapses. Taking in consideration the alignment of the actual and past sinkholes, these alignments need to be reinforced in order to avoid future disasters in that area. As demonstrated in our study, the real costs of damages are much higher in the indirect damage of such sinkhole events rather in the reconstruction of the disaster site itself. Unfortunately, the enforcement of the potential subsidence areas did not take place yet, as demonstrated by a new sinkhole in 2014 in a zone where the vulnerability has been previously emphasized. 


\section{References}

AIHE: Estadísticas, Asociación de la Industria Hidrocarburífera del Ecuador, Quito, Asociación de la Industria hidrocarburífera del Ecuador (AIHE), Quito, Ecuador, available at: http://www.aihe.org.ec/index.php?option=com_content\&view= article\&id=122: estadisticas\&catid=67\&Itemid=142, 2015.

Cowen, T. (Ed.): Public Goods and Market Failures, Transaction Publishers, New Brunswick, NJ, USA, 1992.

Explored: Obra vial desaparece en la capital después de 40 años, Explored Noticias Ecuador publicado en 1 enero 2009, http://www.explored.com.ec/noticias-ecuador/ nuevo-colector-ya-funciona-en-el-trebol-437565.html, 2009.

National Institute of Meteorology and Hydrology (INAHMI): Meteorological yearbook, Nr. 48, Quito, Ecuador, 2010.
La Hora: El Trebol se cayó en Quito, Diario La Hora Nacional, sección País, Domingo 6 de abril de 2008, available at: http://www. lahora.com.ec/index.php/noticias/show/703827/1/El_Tr/\%C3/ $\%$ A9bol_se_cay/\%C3/\%B3_en_Quito.html\#.VT4MtJ_NHw, 2008.

Municipio del Distrito Metropolitano de Quito (MDMQ): Balance de los Estudios Urbanos (1985-2005) de la Coperación IRDMunicpio de Quito, in: Movilidad, elementos esenciales y riesgos en el Distrito Metropolitano de Quito, edited by: Demoraes, F., Co-edición MDMQ-IFEA-IRD, Quito, 2005.

O'Rourke, T. D. and Crespo, E.: Geotechnical properties of cemented volcanic soil, J. Geotech. Eng., 114, 1126-1147, 1988.

Peltre, P.: Quebradas y riesgos naturales en Quito, in: Riesgos Naturales en Quito, edited by: Pierre, P., Corporación Editora Nacional, Quito, Ecuador, 45-89, 1989. 